\title{
Numeral Classifiers in Udi: A Unique Contact- Induced Development among Nakh-Daghestanian?
}

\author{
Timur Maisak \\ Senior Researcher, Department of Caucasian Languages, Institute of \\ Linguistics RAS, Moscow, Russia \\ Leading Researcher, Linguistic Convergence Laboratory, HSE University, \\ Moscow, Russia \\ timur.maisak@gmail.com
}

\begin{abstract}
Following Stilo's (2018) study of small-inventory classifier systems in a number of Indo-European, Turkic, Kartvelian and Semitic languages of the Araxes-Iran Linguistic Area, the paper presents an account of numeral classifiers in Udi, a NakhDaghestanian (Lezgic) language spoken in northern Azerbaijan. Being a peripheral member of the linguistic area in question, Udi possesses an even more reduced version of a small-classifier system, comprising one optional classifier dänä (Iranian borrowing, most likely via Azerbaijani) used with both human and inanimate nouns. A dedicated classifier for humans is lacking, although there is a word tan (also of Iranian origin) only used after numerals or quantifiers, but predominantly as a noun phrase head. The behaviour of dänä and tan is scrutinized, according to a set of parameters, in both spoken and written textual corpora of the Nizh dialect of Udi. Drawing in the data from the related Nakh-Daghestanian languages, the paper shows that among the languages of the family Udi may be unique in possessing classifiers (albeit as a result of contact), Khinalug possibly being the only other exception.
\end{abstract}

\section{Keywords}

contact-induced change - numeral classifiers - Udi - Azerbaijani - Lezgic - NakhDaghestanian - Turkic - Iranian - Araxes-Iran Linguistic Area 
In his recent paper, Don Stilo (2018) reports the existence of small-inventory classifier systems as an areal trait of the languages belonging to the Araxes-Iran Linguistic Area (AILA), which covers Georgia, Armenia, Azerbaijan, northern and central Iran, northern Iraq, and Eastern Turkey. Numeral classifiers are robust in about half of the AILA languages, and represent simple systems, generally consisting of only two classifiers: a universal numeral classifier with the original meaning 'seed, grain' used for all noun types (including human), and a numeral classifier meaning 'person' optionally used for humans (Stilo, 2018: 135-137). The classifiers in question are sortal numeral classifiers and not mensural numeral classifiers. That is, they mostly co-occur with nouns of high countability (in terms of Gil, 2013), and do not describe units of measure.

In particular, such simple systems of numeral classifiers exist in the Turkic languages of the area, Azerbaijani and Turkish, which have borrowed the word meaning 'seed, grain' from Iranian. Azerbaijani dialects have three variants of the universal numeral classifier, namely dance, dana and dcence. The human numeral classifier ncefer, also found in most Iranian languages, is ultimately an Arabic loan. Examples (1) and (2) show the use of the two classifiers in the Tabriz Azerbaijani dialect of Northern Iran.

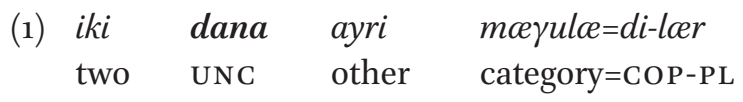

'They are two different categories.' (Stilo, 2018: 138)

(2) šah döwrce-sin-dce beš on næefar adam gïzїl-̈̈

king around-3s:POss-LOC five ten HNC person gold-ACC čij-ar-di-lar.

come.out-CAUS-PST-PL

'The Shah (and) five (or) ten people around him got the gold out.' (Stilo, 2018: 144)

Stilo's data on the AILA are restricted to the colloquial registers of the languages and come from published corpora and grammars, occasionally supplemented by his own fieldwork. The two colloquial Azerbaijani examples (1) and (2) are taken from Kiral (2001). For Standard Azerbaijani of Azerbaijan, the existence of classifiers is also acknowledged in the traditional grammar. Thus, Širaliev and Sevortjan (1971: 73) mention a few "explicative numerative words" (pojasnjajuščie numerativnye slova) which can occur between a numeral and a noun, namely nəfar 'person', baş 'head', dənə 'grain', adəd 'number', göz 'eye'. 
See (3), where the examples are given in the modern Latin-based script instead of the original Cyrillic one. ${ }^{1}$

$\begin{array}{ll}\text { (3) } \begin{array}{l}\text { üc nafar adam } \\ \text { beş baş mal }\end{array} & \text { [three CLSF person] } \\ \text { iki dəna alma CLSF cattle] } & \text { [two CLSF apple] } \\ \text { beş ədəd qalam } & \text { [five CLSF pen] } \\ \text { iki göz otaq } & \text { [two CLSF room] }\end{array}$

'three people'
'five cattle units'
'two apples'
'five pens'
'two-room flat'

(Širaliev and Sevortjan, 1971: 73)

In terms of language varieties, the Araxes-Iran Linguistic Area comprises 6o65 languages and dialects, including Kartvelian (Georgian, Laz, Mingrelian), Turkic (Azerbaijani and eastern Turkish dialects, Turkmen of Iraq), Semitic (Neo-Aramaic and Arabic dialects), Nakh-Daghestanian (Udi) and IndoEuropean, in particular Armenian and many Iranian varieties of Northwestern and Southwestern groups (Stilo, 2015: 343-344). Besides Udi, Stilo (2015:344) also lists Kryz, Aghul and Tsakhur as three more Nakh-Daghestanian languages to be included in the future Atlas of the AILA (like Udi, all three belong to the Lezgic branch). At the same time, in other works on the areal phenomena in the AILA, it is usually just Udi which is mentioned (see e.g., Stilo, 2014: 271 and Noorlander and Stilo, 2015: 427). This is not surprising, as Udi is spoken in the southernmost part of the Nakh-Daghestanian-speaking area, and has been for millennia in tight contact with the unrelated languages of the Eastern Transcaucasia, namely Armenian, Iranian and Turkic (see also below). Although Stilo (2018) does not present any data on Nakh-Daghestanian languages, in an earlier brief description of the isogloss "Classifier between numeral and noun" in the AILA, Udi is mentioned as one of the non-Iranian languages which borrowed the Iranian word for 'seed, grain' as a classifier (Stilo, 2014: 278). As Stilo (2014: 279) further elaborates, "classifiers seem to be only marginal in the corpus of Oktomberi (Georgia) dialect", where only one token of dana, an Azerbaijani borrowing, is attested in a small text corpus, recorded by Alice Harris.

In what follows, I take up Stilo's (2014: 279) proposal that "[o]ther [Udi] dialects still need to be investigated", and look in more detail at the major Udi dialect currently spoken in Azerbaijan, namely the Nizh dialect. As it happens, Nizh Udi also possesses a small-inventory classifier system, albeit even more reduced than the ones described by Stilo (2018) for some of the AILA languages.

1 Letter $ə$ in the Azerbaijani alphabet corresponds to /æ/ in Stilo's transcription and to /ä/ in my transcription of Udi examples below. 
In particular, the word dänä is employed, in postposition to numerals, with both human and non-human nouns. Although there is no corresponding human classifier like nafar, there is a word tan 'person' which predominantly functions as the head of noun phrases, although it is restricted to contexts with numerals (or quantifiers). Examples (4) and (5) illustrating dänä and tan are both taken from the Nizh Spoken Corpus (henceforth NSC; the year when the text was recorded is added in brackets).

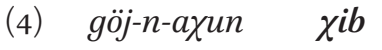

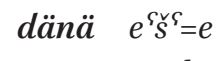
bist:a
sky-OBL-ABL three CLSF apple $=3 S$ fall + PRS
'Three apples fall from the sky.' (NSC, 2002)
(5) beš
ajl-in
boš
$u^{\varsigma} \boldsymbol{q} \quad \boldsymbol{t a n}=j a n$
we:GEN family-GEN inside six PERSON=1PL
'In our family, there are six people (lit. we are six people).' (NSC, 2004)

I start in Section 2 with a basic overview of Udi and its contact situation, as well as the data used for the study. Section 3 describes the use of the universal classifier dänä in both spoken and written corpora of Nizh Udi according to a set of parameters. In particular, I look at the frequency of occurrence of this word with different numerals and with different nouns, and also at the degree of its obligatoriness (e.g., presence vs. absence of dänä in numeral phrases). In Section 3, the distribution of the word tan is explored. While this word is similar to a numeral classifier in that it occurs only with numerals (also with some quantifiers), it is not a classifier as such, as it is almost never found in the "numeral - classifier - noun" construction, but only as the NP head. Section 4 contains the discussion of whether Udi can be said to possess a system of numeral classifiers at all, given that the system only includes one element. Also, I look at some other languages of the Lezgic branch (and also Khinalug spoken in the same area) in order to find out whether the existence of a classifier system in Udi is unique among the Nakh-Daghestanian family. The paper ends with the conclusion, in which I summarize the data on the Udi classifier system as demonstrating clear 'fade-out' effects within the Araxes-Iran area.

\section{Basics on Udi and the Available Textual Data}

Udi is a language of the Lezgic branch of the Nakh-Daghestanian family (also known as East Caucasian family). The Nakh-Daghestanian languages are spoken in the eastern part of the Caucasus, mainly in the Russian republics of Daghestan, Chechnya and Ingushetia, as well as in the adjacent regions of Azerbaijan and 
Georgia. The major branches of the family are Nakh, Avar-Andic, Tsezic, Dargwa, Lak, Lezgic and Khinalug, of which Lak and Khinalug are single-language branches. ${ }^{2}$ The Lezgic branch includes nine languages, three of which (Archi, Tabasaran and Agul) are spoken in the Republic of Daghestan, three more (Lezgian, Tsakhur and Rutul) are spoken both in Daghestan and in Azerbaijan, and the remaining three (Kryz, Budugh and Udi) are spoken only in Azerbaijan.

Genealogically, Udi is a peripheral member of the Lezgic branch. It is considered to be the first language to have separated from Proto-Lezgic (Alekseev, 1985; Kassian, 2015). The ancestor of Udi is Caucasian Albanian (or Aghwan), the only Nakh-Daghestanian idiom with an ancient written tradition, an alphabet having been created for it in the 5 th century AD (Schulze, 2015a). Although the Caucasian Albanian alphabet was only rediscovered in the 1930s, the decipherment of the palimpsests found in St. Catherine's Monastery on Mt. Sinai several decades later (and published in Gippert et al., 2008) provides an insight into the remote history of the language.

Geographically, Udi is the southernmost outlier of the family. Although historically the language was spoken over a broader territory, by the 2oth century there were only two large settlements left: the town of Vartashen (now $O \breve{g} u z$, center of the modern Oğuz district of Azerbaijan) and the village of Nizh (Nic, located in the modern Qabala district of Azerbaijan). Each of these two places had its own dialect, with differences both in the grammatical structure and the lexicon. In early 1920s, the small Udi village of Zinobiani (known as Oktomberi in Soviet times) was founded in the Kvareli district of Georgia by a group of resettlers from Vartashen. The end of the 2oth century saw a massive outflow of Udis from Azerbaijan, especially from Vartashen, where currently only a few families remain. The largest Udi-speaking settlement today is the village of Nizh with ca. 3,500-4,00o Udi speakers. There are about 200-300 Udis in Zinobiani, although the language is highly endangered there. By now, more than a half of all Udis $(4,267$, according to the 2010 census) live in Russia, especially in the Krasnodar, Rostov and Stavropol regions in the southern part of the country. The total number of Udis can be estimated at 8,00o to 10,000.

Due to its geographical position, contact between Udi and the genealogically unrelated languages of the area has been intense. Schulze (2001/2) identifies several chronological layers of contacts in the history of Udi, including those with Old and Middle Iranian varieties (Median, Persian, Northwest Iranian), Talyshi and Jewish Tati, Old, Middle and Modern Eastern Armenian,

2 For an overview of the Nakh-Daghestanian language family, see van den Berg (2005) and Ganenkov and Maisak (2020). 
Azerbaijani, Russian and Georgian (mainly in Zinobiani). ${ }^{3}$ As regards modern Udi, it is generally assumed that while the Vartashen dialect was more subject to Armenian influence, Azerbaijani had (and still has) a considerable impact on the Nizh dialect. For centuries, Azerbaijani has been the second language of the Nizh Udis and the main source of contact-induced language change (see especially Gukasjan, 1973). The Azerbaijani influence can be seen on various linguistic levels, including phonology, lexicon, and morphosyntax. Thus, there is a whole number of morphemes borrowed from Azerbaijani, such as the suffix -(i)mร̌i which derives ordinal numerals from cardinal bases, the adjectival suffix - lu 'related to X' and the caritive suffix -suz 'not having X', the suffix of abstract and status nouns - $-l u s$ and the agent noun suffix - či, among others (see Schulze, 2016b for examples). There are also quite a few particles, conjunctions and postpositions copied from Azerbaijani (some of them ultimately of Arabic or Persian origin), such as the very frequent subordinator $=k i$, the conjunctions ägär 'if', joxsa 'or' and čunki 'because', the postpositions görä 'for the sake of' and barada 'about', or the conditional enclitic $=s a$, which also became part of the indefinite pronoun marker $=(n) e s a($ Maisak, 2019).

It is harder to capture the Iranian impact on the Udi morphosyntax, which rather displays itself in certain "suspicious" structural parallels. Schulze (2015b) discusses the emergence of Split-O strategies (a.k.a. Differential Object Marking) in Caucasian Albanian and Udi and the development of a system of "floating" agreement clitics as possible influences of the Iranian languages of the area. He admits, however, that one cannot exclude the possibility that the Split-O strategy "has emerged also from contact with Old Armenian and that it has been reinforced later-on by the strategy of definitive [definite - T.M.] object marking in Oghuz Turkic" (Schulze, 2015b: 388). Accordingly, we cannot assume that "the technique of applying floating agreement clitics itself has been borrowed from a late Medieval Northwest Iranian language into Udi": rather, what we see is the case of "some kind of functional borrowing that dwells upon given strategies of agreement marking and upon the corresponding native material" (Schulze, 2015b:398). Still, on the whole, as Schulze (2015b: 398) puts it, the "impact from Armenian and Iranian languages resulted in significant shifts with respect to both the lexicon and the grammar of C[aucasian] A[lbanian] / Udi that set both languages apart from the world of Lezgian languages". As the result, the linguistic structure of modern Udi is quite different from a "standard average" Nakh-Daghestanian language on many levels.

3 See also Schulze (2005; 2016a), and particularly Schulze (2002) on Udi-Armenian and Schulze (2015b) on Udi-Iranian contacts. 
The existence of numeral classifiers in Udi, which are unheard of in the other Nakh-Daghestanian languages, is a clear example of a contact-induced phenomenon. With respect to nominal morphology and the syntax of noun phrase, the languages of the family are very much alike. Nouns inflect for number (singular and plural) and case. The number of cases can be very high, as in addition to the "core" grammatical cases like the ergative, absolutive (nominative), dative or genitive most languages possess a set of bimorphemic (or sometimes trimorphemic) locative forms, see Kibrik (2003) and Daniel and Ganenkov (2009). In most languages, there is a category of gender (noun class) which displays itself in agreement; gender agreement was completely lost in Udi, as well as in Lezgian and Agul. Noun phrase dependents are prenominal and typically include adjectives, demonstratives, genitives, numerals and participial clauses. With numerals, nouns tend to occur in the singular. One thing which seems to be definitely lacking in the languages of the family are classifiers, including numeral classifiers. To my knowledge, the existence of such grammatical devices has never been described for any Nakh-Daghestanian language (neither in individual grammar sketches, nor in general cross-linguistic studies like Aikhenvald, 2000 or Gil, 2013). Neither dänä nor tan are mentioned by Schulze $(2015 \mathrm{~b})$ describing the effects of Udi-Iranian language contact, although his paper does not claim to give an exhaustive list of Iranian borrowings in the Udi lexicon or morphosyntax. ${ }^{4}$

In the present study, I rely on corpus examples of the use of dänä and tan which is similar to the approach of Stilo (2018). I do not restrict myself to the colloquial data, though. Besides the Nizh Spoken Corpus collected in the 20oos by Dmitry Ganenkov, Yury Lander and myself, I also look at the written texts published in Nizh Udi since 199os. These texts include ABC books and school textbooks, collections of folklore and original and translated prose and poetry, as well as the translations of the Gospel of Luke and two smaller Bible books. The data on the corpora is summarized in Table 1 , were I list the approximate size of publications and give short descriptions of their content. In total, I take into account ten books in Nizh Udi published from 1996 to 2013, which make together ca. 90,000 words, and a spoken corpus of Nizh Udi comprising 12,500 words.

4 I want to mention, however, that that I first heard the suggestion to treat dänä as a classifier from my colleague Yury Lander (Institute of Oriental Studies RAS / Higher School of Economics, Moscow), back in the early 2000 when we analysed our first recordings of Nizh texts (with our third team member Dmitry Ganenkov). Also, Lander (2013) mentions dänä and tan (as "numeratives") among the contact-induced features in the Udi noun phrase, alongside phrase marking and the adrelative genitive construction. 
TABLE 1 Textual sources for the present study

\begin{tabular}{|c|c|c|}
\hline Source & Size (words) & Description \\
\hline $\begin{array}{l}\text { Aydınov and } \\
\text { Keçaari (1996a) }\end{array}$ & 3,100 & АBC book: words, sentences, short texts \\
\hline $\begin{array}{l}\text { Aydınov and } \\
\text { Keçaari (1996b) }\end{array}$ & 3,800 & 3rd grade textbook: short texts, questions \\
\hline Keçaari (1996) & 10,700 & $\begin{array}{l}\text { Collection of original prose (short stories) } \\
\text { and poetry by various Udi authors }\end{array}$ \\
\hline Keçaari (2001) & 19,100 & $\begin{array}{l}\text { Collection of prose (legends, anecdotes, } \\
\text { one play) and original and translated } \\
\text { poetry by Georgij Kechaari }\end{array}$ \\
\hline Keçaari (2003) & 8,800 & $\begin{array}{l}\text { Collection of original and translated poetry } \\
\text { by Georgij Kechaari }\end{array}$ \\
\hline Ruth-Iona (2009) & 2,500 & The Book of Ruth, the Book of Jonah \\
\hline Luke (2011) & 19,400 & The Gospel of Luke \\
\hline $\begin{array}{l}\text { Miller and } \\
\text { Antonova (2012) }\end{array}$ & 8,300 & $\begin{array}{l}25 \text { short stories from the Bible, with } \\
\text { questions for readers (translated) }\end{array}$ \\
\hline Dabakov (2007) & 10,400 & $\begin{array}{l}\text { Collection of prose (legends, fairy tales), } \\
\text { some of which are taken from Keçaari } \\
(2001) \text {, sometimes slightly edited }\end{array}$ \\
\hline Dabakov (2013) & 3,000 & $\begin{array}{l}\text { ABC book: words, sentences, short texts } \\
\text { (sometimes with the Russian translation } \\
\text { and/or the Vartashen Udi equivalents) }\end{array}$ \\
\hline $\begin{array}{l}\text { written texts: } \\
\text { total }\end{array}$ & 89,100 & \\
\hline $\begin{array}{l}\text { Nizh Spoken } \\
\text { Corpus (200os) }\end{array}$ & 12,500 & $\begin{array}{l}\text { Short narratives (biographical texts, } \\
\text { anecdotes, fairy tales), traditional practices } \\
\text { (wedding, funeral, etc.), traditional recipes }\end{array}$ \\
\hline
\end{tabular}

\section{$3 \quad$ Numeral Phrases with dänä in Nizh Udi}

The word dänä which functions as a numeral classifier must have been borrowed already in the classifier function, as it is not normally used with the meaning 'grain, seed' in modern Udi. A cognate word dän is mentioned in the Udi-Azerbaijani-Russian dictionary by Gukasjan (1974: 110) with the meaning 'grain, corn (зерно, крупинка)'. ${ }^{5}$ It corresponds directly to the Azerbaijani dən

5 Also in Mobili (2010: 96), which is a new and slightly updated edition of Gukasjan's dictionary employing the new Azerbajiani-based Udi alphabet. 
with the same meaning (see also Schulze, 20o1: 269). In Nizh Udi this word seems to be uncommon, and I came across a single example of its use in the 2011 translation of the Gospel of Luke, see (6). Here, dän is used in the mass meaning 'grain which is being ground', not in the singulative meaning. Other words with similar meaning include kračs ${ }^{\varsigma}$ 'grain, kernel' and cril 'seed'.

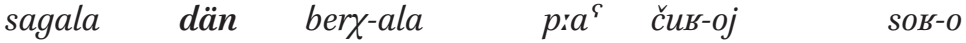

$$
\begin{aligned}
& \text { together grain grind-PT:IPF two woman-GEN one-NMLZ } \\
& \text { 'one of the two women grinding together (at the same place)' (Luke, } \\
& \text { 2011; Lk. 17:35) }
\end{aligned}
$$

The word dän for 'grain' is also attested in the late 19th century Gospels translation into the Vartashen dialect (Bežanov, 1902), ${ }^{6}$ where it occurs three times, in Mk. 4:28, Mk. 4:31 (written as tän and together with the next word) and Jo. 12:24, cf. bui dän 'mature grain', arumun dän 'kernel of wheat'. A small Udi-German dictionary by Fähnrich (1999: 14) representing the Oktomberi variety does not mention dän.

As for dänä, Gukasjan (1974:110) and Mobili (2010: 96) translate it in Russian as 'štuka (штука),', i.e., 'piece, unit', a counter word for inanimates in Russian. The Udi word is again identical to the Azerbaijani dana, cf. the example given by Gukasjan: $\chi i b$ dänä, Azerbaijani üç dənə 'three (pieces, items)'. The word is mentioned neither in Fähnrich's (1999) dictionary of the Oktomberi Udi nor in Schulze's (2001) index of the Vartashen lexicon from the 19th century Gospels translation.

If we look now at the distribution in the modern Nizh text corpora (Table 2), we immediately see that the overall frequency of dänä is low. ${ }^{7}$ In all the texts I analysed, dänä occurs only 48 times (per more than 90,0oo words). Thus, dänä does not look like a highly grammaticalized item. The second observation which can be made from Table 2 deals with the asymmetry between the written texts and the spoken corpus: the overwhelming majority of all uses (40 of 48) is found in the latter. The ratio of dänä occurrence per one thousand

6 The translation was made in 1893 by the Vartashen priest Semën Bežanov, with the help of his brother Mikhail Bežanov. Schulze (2001) is a republished edition in Latin transcription, supplied with an introduction, a dictionary (with etymological notes) and concordances.

7 I have omitted one example from the counts, which reads: bezi här däninäzun, vi p:ijan avuzbo hun 'From each of my seeds, you will strengthen your blood' (Aydınov and Keçaari, 1996b).

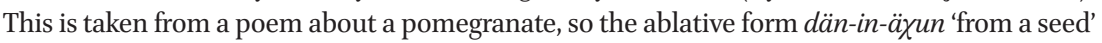
refers to a pomegranate seed. The example is interesting in that due to its inflection class dänin-äzun can be only a form of the word dänä, not dän (only vowel-final nouns have an oblique stem -in- in Nizh Udi). Thus, dänä here is used not as a classifier, but as a noun 'seed', which may point at a kind of confusion between dänä and dän with this meaning. 
TABLE 2 Frequency of dänä in the Nizh Udi corpora

\begin{tabular}{lll}
\hline Source & dänä & $\begin{array}{l}\text { dänä } \\
\text { per 1,0oo }\end{array}$ \\
\hline Aydınov and Keçaari (1996a) & 0 & 0 \\
Aydınov and Keçaari (1996b) & 0 & 0 \\
Keçaari (1996) & 0 & 0 \\
Keçaari (2001) & 1 & 0 \\
Keçaari (2003) & 0 & 0 \\
Ruth-Iona (2009) & 0 & 0 \\
Luke (2011) & 6 & 0.31 \\
Miller and Antonova (2012) & 0 & 0 \\
Dabakov (2007) & 0 & 0 \\
Dabakov (2013) & 1 & 0.33 \\
Nizh Spoken Corpus (2000s) & 40 & $\mathbf{3 . 2}$ \\
total & 48 & 0.5 \\
\hline
\end{tabular}

words is the highest in the spoken corpus and reaches 3.2 words. In the Gospel of Luke with its 6 occurrences of dänä this ratio is much smaller (o.31).

As already illustrated in (4) above, dänä occurs in the "numeral - classifier noun" construction, with only a few deviating instances. Below, I characterize the construction with dänä from the point of view of the numeral type, the noun type and the general NP structure. I will then discuss the degree of optionality of the classifier.

\subsection{Numeral Type}

In Udi, cardinal numerals from ' 1 ' to ' 10 ' (and also ' 20 ' and '10o') represent dedicated non-derived words. Numerals from ' 11 ' to '19' are historically combinations of a simple numeral from ' 1 ' to ' 9 ' with a root for ' 10 ', although synchronically the combinations are morphologically idiomatic (e.g., pracicie '12', but cf. p: $a^{\varsigma}$ ' 2 ' and vic: ' 10 '). Words for tens higher than ' 20 ' in the modern Nizh dialect are Azerbaijani loans (e.g., otuz '30', qitr '40', etc.). The word hazar for '10oo' is also a borrowing. All other numerals are compound formations.

All the uses of dänä attested in the corpus are with low numerals of the first ten. Among these, 'one' is by far the most frequent, accounting for half of all examples (24 occurrences), see (7) for illustration. Other numerals from ' 2 ' to ' 10 ' (and with the exception of ' 9 ') occur with dänä from 1 to 6 times each. In four instances, it is not one numeral but an approximation interval with two numerals that appears in the numeral phrase, e.g., ' $2-3$ barrels' or ' $4-5$ guests', see (8). 


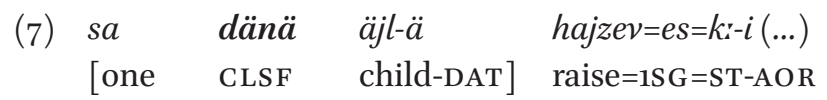

'I asked one pupil to stand up (lit. raised one pupil).' (NSC, 2004)

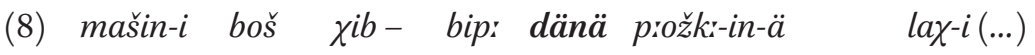
car-GEN inside [three four CLSF barrel-OBL-DAT] put.above-AOC 'Having put three or four barrels in a car.' (N SC, 2004)

As the next examples show, the numeral $s a$ 'one' in Udi can be used as an approximation marker 'about, roughly' before a numeral phrase, be it with a single numeral (9) or with an interval (10). In such instances, I didn't count sa as a numeral proper within the numeral phrase - e.g., in (10), I only counted ' $4-5$ ' as numerals.

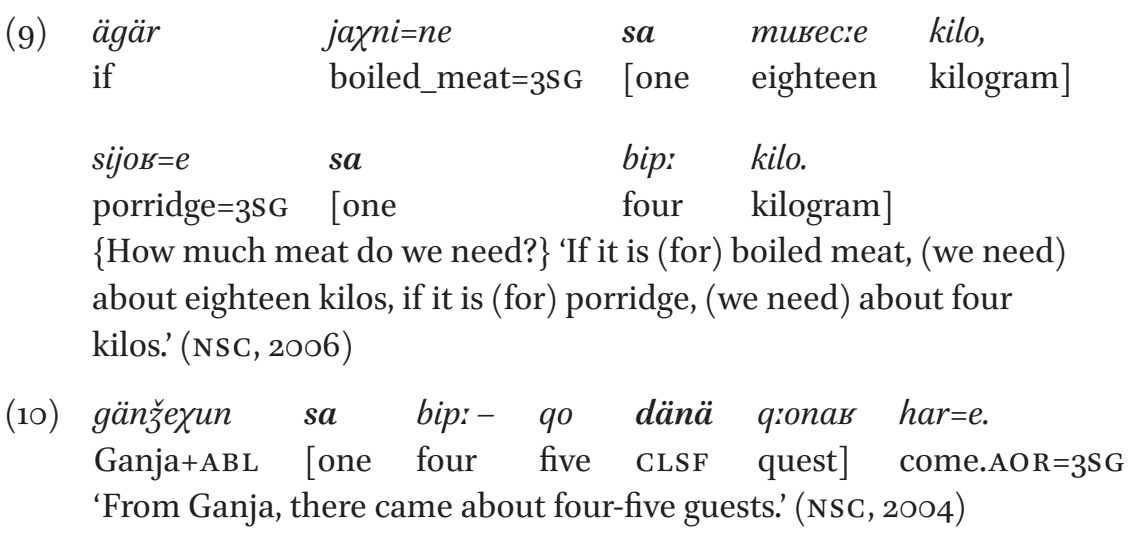

Another non-numeral function of 'one', very common in Udi as well as in other Nakh-Daghestanian languages and in languages of the Araxes-Iran Linguistic Area, is indefiniteness marking: $s a$ is used regularly as a kind of weakly grammaticalized indefinite article, especially in introductory contexts, see (11). There are some instances of the "numeral 'one' - classifier - noun" construction, where $s a$ seems to be used in the indefinite article function, as in (12). I will return to the problem of the numerical use of 'one' and the indefiniteness use when discussing the structure of NP s with a classifier.
(11) beš
$\begin{array}{ll}\text { ajiz-e izvestni } & \\ \text { village-LOC } & \text { [famous }\end{array}$
sa amdar $=e \quad b a k-s a, i z$
we:GEN

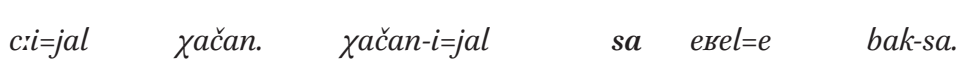
one person] $=3$ SG be-PRS self:GEN
name $=$ ADD Khachan Khachan-GEN=ADD [one sheep] $=3$ SG be-PRS
'There is a famous man in our village, his name is Khachan. And Khachan has a sheep.' (NSC, 2004) 


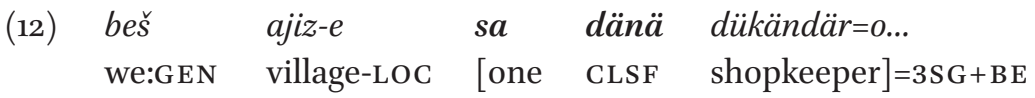

'There is a shopkeeper in our village.' (N SC, 2004)

\subsection{Noun Type}

It should be obvious from examples already cited above that the classifier construction with dänä can have both inanimate and animate nouns as its head, cf. 'apple' (4), 'barrel' (8), but also 'child' (7), 'guest' (10), 'salesman' (12). In total, there are 26 uses of dänä with inanimate nouns and 22 uses with animate nouns (in a few cases, the noun is omitted, but the referent is detectable from the context).

Among the animate nouns occurring with dänä we find general words for people ('person', 'child', 'woman'), kinship terms ('daughter', 'son'8) and a number of other items ('friend', 'guest', 'salesman', 'bride', etc.), including the word 'spirit' (in the Biblical context), see (13) and (14).

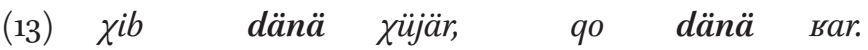

[three CLSF daughter] [five CLSF son]

\{My mother had eight children:\} 'three daughters and five sons.' (NSC, 2002)

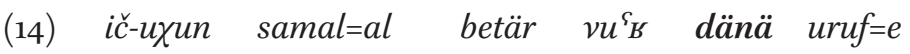
[self-ABL a_little=ADD wicked seven CLSF spirit]=3SG

ex-stra.

take-LV+PRS

\{Then it goes and ' takes seven other spirits more wicked than itself.'

(Lk. 11:26)

Inanimate heads attested with the classifier include artifacts ('boat', 'barrel', 'plate'), food and fruit ('bread', 'tea', 'apple', 'chestnut', 'mustard seed'), place names ('village', 'Nizh', 'room') and some abstract nouns as well ('interesting incident', 'choice', 'variant'). In a few cases, a noun seems to have a preferred mass reading (e.g., 'tea' or 'money'), so the use of dänä may be caused by the need to make the noun countable. On the whole, however, dänä preferably occurs with concrete nouns and is not attested with time units (like 'day', 'year') nor measure words (like 'kilogram' or 'litre').

8 Like in many Nakh-Daghestanian languages, words for 'daughter' and 'son' in Udi also have the more general meanings 'girl' and 'boy', respectively. 


\subsection{Structure of an NP}

The standard construction "numeral - classifier - noun" with dänä following a numeral and the phrase-final head noun has been illustrated in a number of examples above. Here, I describe expansions of, or deviations from, this basic pattern.

First, in several N P s there is also a modifier preceding the head noun, e.g., an adjective (15) or a genitive (16). In numeral phrases, modifiers do not have to occur between the numeral and the head noun, so there are also instances when the whole "numeral - classifier - noun" group is preceded by an adjective (17) or a participial (relative) clause (18).

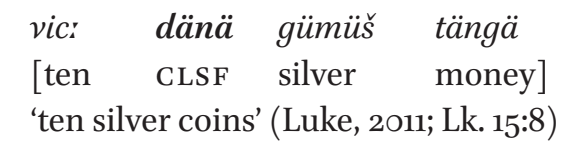

16) dä̈n̈ xardal-i cil-e qä̈där (...)

[one CLSF mustard-GEN seed-GEN] amount

\{If you have faith\} 'as small as a mustard seed.' (Luke, 2011; Lk. 17:6)

$\begin{array}{lllll}a b u z=e=b a k-i & k a l a & s a & \text { dänä } & n i^{\varsigma} \check{z} . \\ \text { enlarge }=3 S G=L V-A O R & {[\text { big }} & \text { one } & \text { CLSF } & \text { Nizh }]\end{array}$

\{From these people\} 'one big Nizh has grown.' (NSC, 2002)

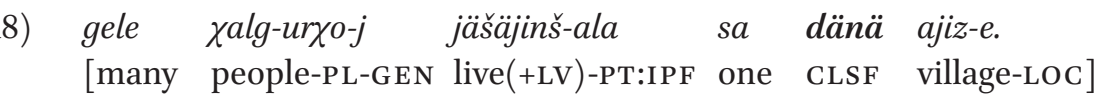
\{They all live\} 'in a village where there live many peoples.' (NSC, 2004)

There is one example which can be interpreted as comprising a mensural classifier between the "numeral - classifier" complex and the head noun, cf. 'about two or three barrels of grapes' in (19). Indeed, words like 'barrel', 'sack', 'bottle', 'spoon' and the like do occur as a kind of mensural classifiers in Udi, e.g., sa müšük: q:iztl [one sack gold] 'one/a sack of gold', sa litir muč: sanaq: [one litre milk] 'one/a litre of milk', sa ajaq: fi [one glass wine] 'one/a glass of wine', etc. Unlike dänä, all such words are not function words, but regular nouns. As we see in (19), the sortal classifier dänä, which always directly follows the numeral, precedes a mensural classifier in an NP.

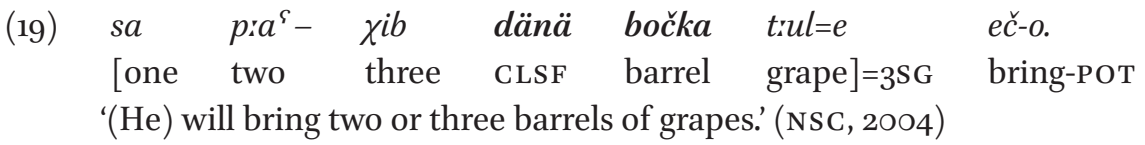


In the spoken corpus, which reflects spontaneous speech, one can occasionally find an NP where another argument interferes between the "numeral classifier" complex and the head noun, cf. (20) where the benefactive 'for himself' is scrambled. Also, (21) is an example where the "numeral - classifier" combination is added clause-finally, while the standard variant would have been sa dänä he 'one what-d'ya-call-it.'

(20) tiejin sa dänä ič-ejna vibor črev=e=kr-on. from_there [one CLSF self-BEN choice] take_out=3SG=ST-POT 'Maybe he will draw from this some conclusion ${ }^{10}$ for himself.' (NSC, 2004)

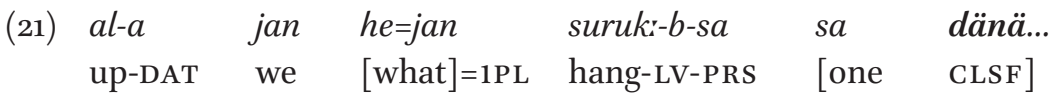

'We hang up there one what-d'ya-call-it.' (NSC, 20o6)

In a few "numeral - classifier - noun" constructions, there is in fact no noun, which is either dropped under ellipsis or is left unpronounced because a speaker does not finish a sentence. In (22), describing a greedy person, headless sa dänä occurs in subject position of a copular clause.
(22) sa dänä=ne uk-sun-astia čuk-sun-astia haqi-sun-astia (...) [one CLSF] $=3 S$ G eat-MSD-AD tear_off-MSD-AD take-MSD-AD ' $(\mathrm{He})$ is the (only) one in eating, in tearing off, in taking away.' (Keçaari, 2001)

\subsection{Optionality of dänä}

To answer the question, whether or not dänä is obligatory or at least frequent in the "numeral - classifier - noun" construction, I counted all occurrences of numerals of the first ten without dänä in the spoken corpus. I only took into account "numeral - noun" constructions, and didn't count nominalized (headless) use of numerals. For the sake of comparison, to the numerals of the first ten I added those of the second ten ('11'-'20'), which are not attested with dänä in texts, but they turned out to be very infrequent. I also looked at approximation intervals (' $1-2$ ', ' $2-3$ ', ' $3-4$ ', ' $4-5$ ') and counted the attested instances of intervals

9 The interrogative pronoun he 'what' in spontaneous Udi speech functions as a lexical filler (placeholder) for both animate and inanimate referents, see Ganenkov et al. (2010).

10 The speaker uses the word vibor ( $<$ Russian 'choice') erroneously, instead of vivod ( $<$ Russian 'conclusion'). 
TABLE 3 Numeral phrases with and without dänä

\begin{tabular}{|c|c|c|c|}
\hline Numeral & $\begin{array}{l}\text { Num dänä } \\
\text { N (total) }\end{array}$ & $\begin{array}{l}\text { Num dänä } \\
\text { N (spoken) }\end{array}$ & Num N (spoken) \\
\hline sa' '1' & 24 & 22 & 165 \\
\hline$p r a^{\varsigma \prime}{ }^{\prime}$ & 5 & 4 & 20 \\
\hline xib '3' & 6 & 4 & 10 \\
\hline bip: '4' & 1 & 1 & 6 \\
\hline qo ' 5 ' & 2 & 2 & 7 \\
\hline$u^{\varsigma} q^{\prime} 6^{\prime}$ & 2 & 2 & 2 \\
\hline$v u^{\varsigma} E^{\prime} 7$ ' & 2 & 1 & 7 \\
\hline mus '8' & 1 & 1 & $\mathrm{O}$ \\
\hline vuj '9' & $\mathrm{O}$ & $\mathrm{O}$ & 1 \\
\hline vic: '10' & 1 & $\mathrm{O}$ & 4 \\
\hline total for '1'-'10' & 44 & 37 & 222 \\
\hline $\begin{array}{l}\text { '11'-'20' } \\
\text { intervals: }\end{array}$ & o & o & 5 \\
\hline $\begin{array}{l}\text { '1-2', '2-3', '3-4', } \\
\text { '4-5' }\end{array}$ & 4 & 4 & 8 \\
\hline $\begin{array}{l}\text { '10-12', '12-15', } \\
\text { '15-20' }\end{array}$ & O & O & 3 \\
\hline
\end{tabular}

with numerals of the second ten. The results are summarized in Table 3, where the numbers for dänä are given separately for all corpora and for the spoken corpus only. Frequencies of numeral phrases without dänä are only given for the spoken corpus.

As Table 3 shows, the use of dänä in the "numeral - noun" construction is by no means obligatory and not even very frequent: dänä is six times less frequent than the absence of a classifier after a numeral. Judging just from the absence in texts, one may conclude that dänä tends not to occur with certain types of nouns. In particular, whereas words denoting time units are very common in numeral phrases, there is no single example of such words in construction with dänä. Without dänä, the words for 'day', 'week', 'month', 'year' and a few other words with temporal meaning occur 42 times, which is more than one fifth of all the uses (23). The most common of them is 'day' (23 occurrences in the "numeral - noun" construction), whose frequent combination with 'one' is, however, mostly used with the indefinite meaning of the latter, i.e., 'one day' ='once, some day'. There are also 8 occurrences of the word 'time, instance' which is never found with dänä (24). As mentioned above, measure 
words like 'kilogram', 'kilometer', 'litre', etc. normally do not occur with dänä, although there is one instance when 'barrel' as a measure unit comes with a classifier (19).

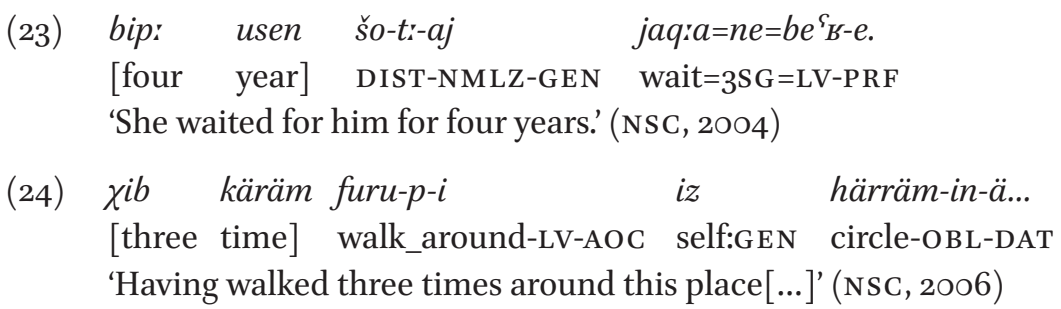

These findings conform to the data discussed by Stilo (2018: 114), who points out that in languages of the Araxes-Iran zone, "sortal classifiers never occur with units of money, time, or measurements". Another observation concerns the restriction of dänä to low numerals (under '1o' only) and its potentially different behaviour with 'one' as a numeral proper and as an indefinite article. Both phenomena are also described by Stilo (2018: 145-151). In particular, his data show that two of the Araxes-Iran languages, namely Colloquial Persian and Muslim Caucasian Tat, have two universal numeral classifiers in complementary distribution, dune/dcence used with the numeral 'one' and $t a / t c e$ with numerals above 'one' and the quantifier 'how many'. Also in Muslim Caucasian Tat, 'one' as a numeral requires a universal numeral classifier, whereas the latter usually does not appear with 'one' as an indefinite article. To the contrary, Azerbaijani and Armenian both show a high use of classifiers with 'one' as an indefinite article with inanimates, but for the numeral 'one' the frequency of use of classifiers is very low (down to zero in Armenian).

As far as Nizh Udi is concerned, the impression one gets from the corpus is that $s a$ 'one' can be used with and without dänä both in the indefinite sense and in the numerical sense. In the overwhelming majority of tokens, sä dänä seems to have numerical value (although there are ambiguous cases). The indefinite reading, however, is not excluded, as illustrated in (25) and (12) above. The indefinite reading of 'one' without dänä is very common, although of course it can simply express quantity as well, as in (26).

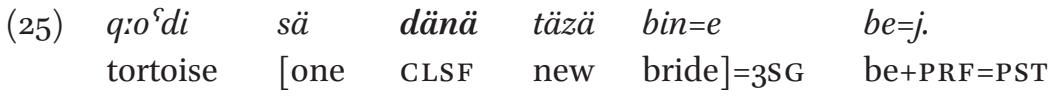

\{From a legend.\} 'A tortoise was a young bride.' (NSC, 2004) 


$$
\begin{aligned}
& \text { sa qoq:la }=l \quad \text { t:a } a^{\Upsilon} \chi=e z=n e \quad \text { iz } \text { boš. } \\
& \text { [one egg]=ADD break=1SG=LV:PRS self:GEN inside } \\
& \text { \{From a recipe.\} 'I also break one egg inside it.' (NSC, 2006) }
\end{aligned}
$$

As a tendency, one can formulate the preference of sä dänä in numerical contexts and its disfavour with the meaning of indefiniteness. It may be that precisely in the case of the numeral 'one' the use of dänä helps to disambiguate between the two functions of this numeral, i.e., dänä serves as a numeral marker proper. Interestingly, there is an example in the spoken corpus which happens to contain two uses of $s a$, one with dänä and the other without dänä (27). If it is not just the case of a "pleonastic" repetition of $s a$ after a modifier, which separates sä dänä from the head noun, then the first occurence must be the numeral 'one' proper, while the second $s a$ is an article. Such order is in line with a tendency to put indefinite $s a$ closer to the head than the numeral,

\begin{tabular}{|c|c|c|c|c|c|c|}
\hline \multirow[t]{4}{*}{$(27)$} & $s a$ & dänä & dirbaš & $s a$ & sar-en & $e^{\varsigma} \chi=e=s t: a$ \\
\hline & [one & CLSF & nimble & one & boy-ERG] & take $=3 S G=L V+P R S$ \\
\hline & $s a$ & döšäj, & $s a$ & $\check{s} e j . .$. & & \\
\hline & & mattress & one & thing & & \\
\hline
\end{tabular}
which is known for Turkish and Azerbaijani and has been at least partly adopted by Udi. ${ }^{11}$

$\{$ Then $\}$ '[...] some nimble boy takes a mattress, some thing.' (NSC, 2006)

\section{Numeral Phrases with tan in Nizh Udi}

Whereas the word dänä is attested in various sources and its etymology and origin is immediately clear, the word tan is more obscure. Gukasjan (1974: 202) and Mobili (2010: 261) translate tan as 'person, man, someone (лицо, человек, некто)'. Already from Gukasjan's short example it is clear that this word has a different Azerbaijani counterpart (nəfər), cf. vic tan 'ten people' and sa tan 'someone, a certain person' in Udi, but on nəfar 'ten people' and bir nafar 'someone, a certain person' in Azerbaijani. Neither Fähnrich (1999: 30) nor Schulze (2001: 323) mention tan which thus looks like a specifically Nizh dialectal item.

Although being translated as 'person, man', the word tan cannot refer to a person outside of the context of numeral or quantifier phrase: (28) shows that

11 While in Turkish, 'one' as an indefinite article follows a prenominal adjective, but precedes an adjective when used as a numeral, in Remo (Munda) and Limbu (Tibeto-Burman) 'one' as an indefinite article follows the noun, but precedes when it is functioning as a numeral (Dryer, 2013). 
only the noun amdar 'person, man' is felicitous in such contexts. To underline the semi-grammaticalized status of tan, I gloss it in examples as 'PERSON' in small capitals.

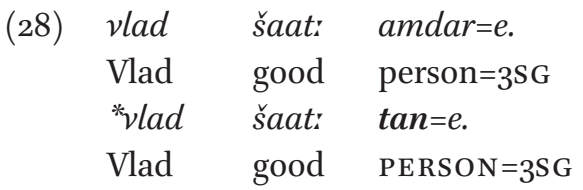

'Vlad is a good person.'

At the same time, the distribution of tan is by no means the same as that of $d \ddot{a} n \ddot{a}$, as the former occurs almost exclusively as the noun phrase head and not in the "numeral - classifier - noun" construction like dänä. The overall frequency of tan is higher than that of dänä, although the two subcorpora where tan is the most frequent are again the Nizh Spoken Corpus (24 times) and the Gospel of Luke (35 times), see Table $4 .{ }^{12}$ Even in these texts, however, the frequency of tan per 1,00o words is lower than the relative frequency of dänä in the spoken corpus. In all its uses, tan refers to humans.

Below, I give a brief characterization of tan-phrases based on what can modify tan as the head. I do not discuss the optionality of tan, because unlike dänä, in its syntactic position tan cannot be omitted. Interestingly, tan seems to be in near-complementary distribution with the "normal" noun for 'person' which is amdar (going back to the lexicalized plural form *adam-ar of *adam, which has been metathesized). The word amdar is very frequent in texts. At the same time, among almost 700 occurrences of amdar, I only found three where it is used in construction with a numeral, namely ' 7 thousand', ' 120 thousand' and 'several hundred'.

\subsection{Numeral/Quantifier Type}

The construction in which tan occurs can be rendered schematically as "numeral/quantifier - noun", because it is not only a numeral that can modify tan. Although in the majority of 85 occurrences, namely 65 , tan comes with a numeral, in 20 cases it is found with one of the following quantifying phrases: hema 'how much?' (8 times), sa hema 'a few' which is a combination of $s a$ 'one' with hema (6 times), or här 'each, every' (6 times, including one instance where it combines with $s a$ 'one' which gives här sa). The next three examples illustrate these uses.

12 In Aydınov and Keçaari (1996a), there is one occurrence of tan which I did not count, as tan occurs simply in the list of words, out of any syntactic context. 
TABLE 4 Frequency of tan in the Nizh Udi corpora

\begin{tabular}{lrc} 
Source & tan & $\begin{array}{c}\text { tan } \\
\text { per 1,0oo }\end{array}$ \\
\hline Aydınov and Keçaari (1996a) & & 0 \\
Aydınov and Keçaari (1996b) & 0 & 0.26 \\
Keçaari (1996) & 1 & 0.28 \\
Keçaari (2001) & 3 & 0.73 \\
Keçaari (2003) & 14 & 0.11 \\
Ruth-Iona (2009) & 1 & 0.4 \\
Luke (2011) & 1 & $\mathbf{1 . 8 0}$ \\
Miller and Antonova (2012) & 35 & 0.6 \\
Dabakov (2007) & 5 & 0.1 \\
Dabakov (2013) & 1 & 0 \\
Nizh Spoken Corpus (2000s) & 0 & $\mathbf{1 . 9 2}$ \\
total & 24 & \\
\hline
\end{tabular}
(29) efi
kroj-a
hema
tan=nan?
you(PL):GEN
house-DAT
[how_many
PERSON] $=2 \mathrm{PL}$

'How many people are there in your family (lit. house)?' (Aydınov and Keçaari, 1996b)

(30) $s a$

\begin{tabular}{|c|c|c|}
\hline hema & $\tan -a$ & jaq: $a=t: u n=b-i$ \\
\hline how_many & 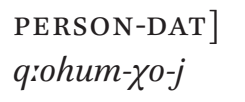 & $\begin{array}{l}\text { send }=3 \mathrm{PL}=\mathrm{LV}-\mathrm{AOR} \\
\text { k:ož-ur } \chi 0\end{array}$ \\
\hline
\end{tabular}

one-NMLZ

relative-PL-GEN house-PL(DAT)

'They sent a few people to the houses of other relatives.' (Keçaari, 2001)

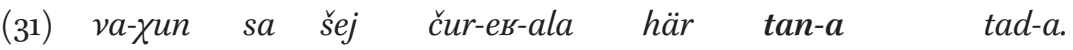
you-ABL one thing ask-LV-PT:IPF [every PERSON-DAT] give-IMP 'Give to everyone who asks you.' (Luke, 2011; Lk. 6:30)

Unlike with dänä, there are no restrictions on using tan with low or high numbers: numerals with which tan occurs range from ' 1 ' to '86oo' (the latter is of course compound, cf. тив hazar u'q bačs tan 'eight thousand six hundred people'), see examples (32) and (33). The phrase sa tan 'one person', besides a literal numerical meaning can also have the meaning 'someone' (or 'anyone', 'no one' in non-affirmative contexts), see (34). 
(32) zarafat te=ne, sacrce tan dav-in-a tas-ala $=n e=j$. joke NEG=3SG [eleven PERSON] war-OBL-DAT do-DEB=3SG=PST 'No joke, eleven men had to go to the war.' (Keçaari, 1996)

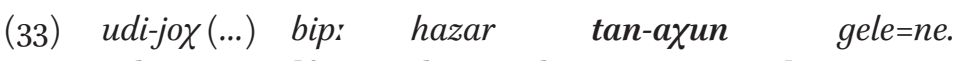
Udi-PL [four thousand PERSON-ABL] many=3SG 'There are more than 4,00o of Udis (in Nizh).' (NSC, 2004)

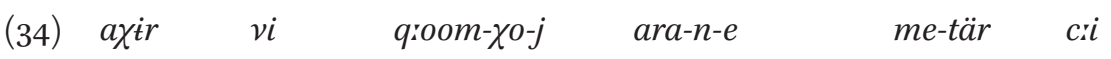
PTCL you:GEN relative-PL-GEN interval-OBL-LOC [PROX-ADV name bak-ala sa tan te=ne=bu. be-PT:IPF one PERSON] NEG=3SG=BE 'There is no one among your relatives who has that name.' (Luke, 2011; Lk. 1:61)

\subsection{Structure of an NP}

As an NP head, tan behaves as any other head noun, i.e., the "numeral/quantifier - noun" complex can be modified by other dependents. Usually, if a modifier is present in corpora examples, this is a preposed relative clause headed by a perfective (35) or imperfective (34) participle. Another attested type of modifier with tan-phrases are adjectives $(36)$ or phrases with the attributive marker -la (37). Also, as a head, tan can take various case inflections depending on the syntactic position, $c f$. the absolutive subject of intransitive verb in $(32,35)$, the absolutive or dative direct object of a transitive verb in $(30,36)$, the ergative subject of a transitive verb in (37), the dative recipient in (31), etc.

$\begin{array}{llll}\text { bandit: } & \text { biqr-s-ejnak: } & \text { har-i } & p a^{\varsigma} \text { tan üše } \\ \text { [bandit } & \text { seize-INF-BEN } & \text { come-PT:PF } & \text { two PERSON] at_night } \\ \text { sun-tr-aj } & \text { kroj-a } & \text { mand-ala=ne } & \text { bak-i. } \\ \text { one-NMLZ-GEN } & \text { house-DAT } & \text { stay-DEB=3SG } & \text { be-AOR }\end{array}$

'Two men, who came to seize the bandits, had to stay for the night at one man's place.' (Keçaari, 2001) 
(36)

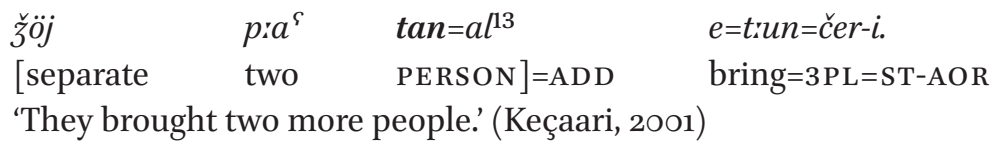

(37)

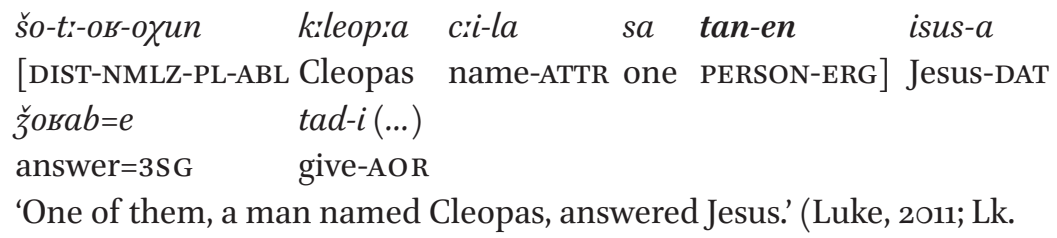

'One of them, a man named Cleopas, answered Jesus.' (Luke, 2011; Lk. 24:18)

Although this may seem trivial, tan as an NP head can co-occur with dänä as a numeral classifier following a numeral, cf. (38), which is however the only example of such kind in the corpus. More interestingly, there is one example where tan itself is used as a classifier (for humans), occuring exactly in the "numeral - classifier - noun" construction, cf. vic: tan žuzamlu, lit. 'ten person leper', in (39). Another similar example of the latter kind is provided by Lander (2013).
har=tiun
tietija $\quad p: a^{s}$
dänä tan.
come.AOR $=3 \mathrm{PL}$
RDP:there [two
CLSF
PERSON]
'Two people came there.' (NSC, 2004)

(39)

$\begin{array}{llllll}i c ̌-u & \text { vic: } & \text { tan } & \text { žuzamlu=ne } & \text { iräst: } & \text { har- }- \text { i. } \\ \text { self-DAT } & {[\text { ten }} & \text { PERSON } & \text { leper }]=3 S G & \text { toward } & \text { come-AOR }\end{array}$

\{As Jesus was going into a village, 'ten lepers met him.' (Luke, 2011; Lk. 17:12)

Still, the use of tan as a classifier proper remains exceptional, and on the whole this item is rather not a "counting" function word, but a regular noun whose use is restricted to numeral and quantifier phrases.

13 Strictly speaking, tanal here can be either the combination of the absolutive tan with the additive enclitic $=a l$, or the dative tan- $a$ with the shorter variant of the additive $=l$ (in the direct object position, both the absolutive and the dative encoding are available). 


\subsection{On the Origin and Spread of the Udi Classifier(s)}

Both dänä and tan are clear cases of borrowings in Udi; it is less clear what the history of their penetration and expansion in the language is. To start with, neither of these two words appears in the Caucasian Albanian texts available to us (Gippert et al., 2008).

The classifier dänä is ultimately of Iranian origin. Given that it exists in Azerbaijani with the same form and function, it is not imposible that it was borrowed into Udi via Azerbaijani, or at least its use in modern Udi may be supported by its use in Azerbaijani. As stressed by Stilo (2014: 272; 2018: 138), the source for this classifier in Azerbaijani is not Persian, but rather various local non-Persian substrate varieties such as Iranian Tati and Caucasian Tat, among others. Note that in Persian the word for 'grain' also used as a classifier for inanimates is the form dāne (colloquial dune), not dänä (Lazard, 1992: 97; Mahootian and Gebhardt, 1997: 195; Windfuhr and Perry, 2009: 478).

The situation with the Udi word tan is more complicated. The origin of this word might be Persian: alongside nafar 'person', tan (colloquial -tcen) 'body' serves as a numeral classifier for humans in Persian (Lazard, 1992: 97; Mahootian and Gebhardt, 1997: 195; Windfuhr and Perry, 20o9: 478). In Azerbaijani, the classifier use of the corresponding word, borrowed in the form $\tan$ (see Section 5.2), seems to be lacking. In its turn, in Udi there are no traces of the original meaning 'body'. However, even if tan was borrowed into Udi from Persian, it seems to reflect the classifier use in a modified way: in (modern) Udi tan is not a classifier as such, but a word for 'person' restricted to numeral and quantifier phrases.

We can thus assume for Udi, that it was probably not the "small classifier system" as a whole that was borrowed. The borrowing of dänä may have happened long ago under local (non-Persian) Iranian influence, or it may be comparatively recent and reflect the growing influence of Azerbaijani. The borrowing of tan was probably an old one and Persian-induced. The two words may have well had different routes into the language and even now do not comprise a single paradigm.

The possibility of an ancient borrowing of tan or even both dänä and tan may seem to be in contradiction to the fact that these two words are attested almost exclusively in modern Udi, and are especially frequent in the recent spoken corpus of 20oos. Indeed, we do not find any mention of dänä in the classifier function in such grammar sketches as Schiefner (1863), Dirr (1903), Šeiranišvili (1971), Pančvize (1974), Schulze (1982) or Schulze-Fürhoff (1994), nor in the texts published by Bežanov (1888) and Dirr (1928), the ABC book 
by Çeirani and Çeirani (1934), or the texts appended to Schiefner's, Dirr's or Žeiranišvili's grammars. ${ }^{14}$ I only managed to single out two occurrences of the word dänä in the meaning 'grain' in one of the texts from Schiefner's (1863: 63) book, namely Ivan Moroz, a translation of a Russian fairy-tale Moroz Ivanovich by Vladimir Odoyevsky. The two occurrences are found in the same sentence

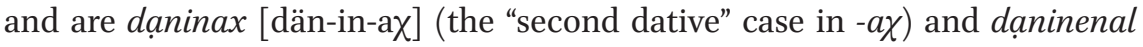
[dän-in-en=al] (the ergative in -en with an additive clitic). As mentioned in Section 3 above, the word dän for 'grain' can be found in the late 19th century Gospels translation into Vartashen dialect (Bežanov, 1902). The word tan for 'person' seems to be first documented only in Gukasjan's (1974) dictionary, where both dän as 'grain' and dänä as a "counting word" are also mentioned (see Sections 3 and 4 for details). The corresponding entries in the dictionary are not labelled for a particular dialect, which usually (although not entirely consistently) implies that the word in question occurs in both Nizh Udi and Vartashen Udi.

The reasons why dänä (as a classifier) and tan remained unnoticed until very recently may be quite different. First, given that these elements are not very frequent in the modern language, it may be that they just did not appear in previously published texts for the same reason. It was shown in Tables 2 and 3 that the classifier dänä is only (relatively) frequent in spoken texts and the 2011 Gospel of Luke translation. Its absence in other texts may be due to the comparatively small size of these publications. It cannot be excluded that at least with respect to a series of books by Aydınov and Keçaari (1996a; 1996b) and Keçaari (1996; 2001; 2003) the author, Georgi Keçaari (1930-2006), one of the first modern Udi writers, poets and folklorists, intentionally avoided some obvious Azerbaijani borrowings and calques.

Another reason may be that, while dänä and (especially) tan appear to be more common in the Nizh dialect, there is some bias in the grammatical sketches produced of Udi so far (and listed above) towards the description of the Vartashen dialect. On the whole, the Vartashen dialect is generally considered to have undergone more influence from Armenian than from Azerbaijani, which may at least partly explain the lack of dänä as a classifier.

In his description of the classifier systems in the Araxes-Iran area, Stilo (2018: 139) mentions that in some languages, e.g., Persian and Armenian, numeral classifiers are "often avoided in the formal written registers" and are more common in the colloquial style. This may be a factor relevant, at least to some

14 For details on the available textual resources for Udi, see also Schulze (2016c). A considerable corpus of published Udi texts (and example sentences from grammar sketches) including Schiefner (1863), Dirr (1903; 1928), Çeirani and Çeirani (1934), З̌eiranišvili (1971) and Pančvize (1974), is available online in the TITUs Text Database (see CPUT, 2010). 
extent, for Nizh Udi as well. Although there is no developed "formal standard" for Udi, it strikes the eye that the overwhelming majority of dänä uses is found in the Nizh Spoken Corpus, but not in the published written prose/poetry.

Finally, as far as the spread of dänä is concerned, it is highly probable that its growing frequency in speech corresponds to the growing use of Azerbaijani among the Nizh Udis in the last decades. Although for the Udis Azerbaijani has been one of the most important contact languages for centuries, knowledge of Azerbaijani among the Udis was not as extensive as knowledge of Russian in the late Soviet period. According to the 1989 census of the USSR, among the 6,125 Udis living in Azerbaijan, 91.8\% were proficient in Udi, 54.5\% in Russian and 34.4\% in Azerbaijani (both as a first and as a second language, and including monolingual speakers, cf. Perepis', 1989). The influence of Azerbaijani increased as of the 199os, when Azerbaijan became an independent state (after the break-up of the Soviet Union in 1991), and Azerbaijani became the country's only official language. Since then, communication in Azerbaijani in official contexts has gradually become the preferred or even the only available option, and the role of Azerbaijani in school teaching has also increased. According to the 2009 Azerbaijani census, 99.6\% of Udis were proficient in Azerbaijani (the numbers for Udi and Russian were respectively $99.3 \%$ and $60.9 \%$, cf. Statistical Committee, 2009). It is precisely during this period when the first recordings of spontaneous narratives in the Nizh dialect appeared, and when the use of the classifier dänä has caught the attention of researchers.

It is worth adding that dänä is not the only instance of contact-induced phenomena seemingly restricted to the Nizh dialect and especially common in the colloquial discourse and recently published texts. Maisak (2019) reports on the borrowing of the Azerbaijani conditional enclitic $=s a$ which came to be used with a range of functions in (at least Nizh) Udi. Like dänä, the clitic =sa cannot be traced in older sources, although it is mentioned (as part of the indefinite pronoun marker) in Gukasjan's (1974) dictionary. Among the modern published texts, the clitic is sporadically attested only in the recent Bible translations (Gospel of Luke, Book of Ruth, Book of Jonah) and the spoken corpus.

\subsection{Is the Udi System Unique among Nakh-Daghestanian?}

The use of numeral classifiers is at best atypical for Nakh-Daghestanian languages. At the same time, although such grammatical means have not been described for any languages of the family, they (in particular, the use of $d \ddot{a} n \ddot{a}$ ) have not been previously described for Udi either. It is thus in principle not impossible that numeral classifiers do occur, albeit peripherally, in some other Nakh-Daghestanian languages besides Udi. Lezgic languages, which are in 
contact with Azerbaijani and might have also borrowed numeral classifiers, are especially likely candidates in this respect. Below, I summarize the data from dictionaries and, to some extent, grammars of the Lezgic languages and Khinalug, looking at the existence (and functions) of words cognate to dänä and words with the meaning 'grain' or 'piece, unit, item' (in counting), cf. штука in Russian.

The comparative dictionary by Klimov and Khalilov (2003: 214), which includes data on Nakh-Daghestanian, West Caucasian and Kartvelian languages, lists Tsakhur dene, Kryz dän, Budugh dan and Udi dänä in the entry for 'grain', with a comment stating the Azerbaijani (and ultimately, Persian) source for these nouns. For Tsakhur, dene is also mentioned as one of the variants for

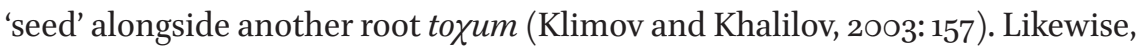
Kibrik and Kodzasov (1990: 110-111), with two separate lexical entries for mass 'grain' and countable 'kernel', give Tsakhur dene, Kryz dän, Budugh dan and Udi dänä in the latter entry, with a note that the Tsakhur word also means 'seed'. In Comrie and Khalilov (2010: 395), a lexical database comprising the three indigenous Caucasian language families as well as Turkic and Iranian languages of the area, the entry for 'grain' includes the same items from Budugh, Kryz, Udi and Tsakhur, plus Azerbaijani dənə. There is no separate entry for 'piece, unit' or a counting word in any of these three dictionaries.

As this comparison shows, a dänä-like word for 'grain' is only attested in southern languages of the Lezgic branch, namely Budugh, Kryz and Udi which are only spoken in Azerbaijan and Tsakhur which is spoken on both sides of the Russian-Azerbaijan border. To these languages, Rutul and Khinalug can also be added: Rutul is the closest genealogical relative of Tsakhur and is also spoken both in Daghestan and Azerbaijan, while Khinalug spoken in Azerbaijan is considered to be a family-level isolate. Words similar to dänä seem to be lacking in East Lezgic languages, namely Agul, Tabasaran and Lezgian, as well as Archi. While the Lezgian-speaking area is vast and covers both southern Daghestan and northern Azerbaijan, Agul and Tabasaran villages are located to the north of the Rutul and Lezgian ones, and Archi is spoken even further to the central part of Daghestan.

The data on the form and attested functions of dänä-like words in Lezgic languages and Khinalug are summarized in Table 5. The sources include available dictionaries and, in some cases, also grammars, excluding Kibrik and Kodzasov (1990), Klimov and Khalilov (2003), and Comrie and Khalilov (2010) whose data were already discussed above. Some sources only mention the lexical meaning 'grain' for a corresponding word. This is, in particular, the case of Kryz according to Authier (2009: 49), and Budugh according to Mejlanova (1984: 50) and Talibov (2007: 25, 104). While the Russian-Rutul dictionary 
TABLE 5 Dänä-like words in Lezgic and Khinalug

\begin{tabular}{|c|c|c|c|}
\hline Language & Word & Meanings & Sources \\
\hline Udi & dän & 'grain, corn' & $\begin{array}{l}\text { Gukasjan (1974: 110), Mobili (2010: } \\
96)\end{array}$ \\
\hline Udi & dänä & 'piece, unit' & $\begin{array}{l}\text { Gukasjan (1974: 110), Mobili (2010: } \\
96 \text { ) }\end{array}$ \\
\hline Kryz & $d \ddot{a n}$ & 'grain' & Authier (2009: 49) \\
\hline Budugh & dan & 'grain', 'kernel' & $\begin{array}{l}\text { Mejlanova (1984: 50), Talibov } \\
(2007: 25,104)\end{array}$ \\
\hline Tsakhur & den & $\begin{array}{l}\text { 'fraction, kernel, } \\
\text { corn' }\end{array}$ & Kibrik and Testelec (1999: 872) \\
\hline Tsakhur & dene & 'piece, unit' / & $\begin{array}{l}\text { Ibragimov and Nurmamedov } \\
(2010: 150)\end{array}$ \\
\hline & & 'grain', 'kernel', 'seed' & (other sources) \\
\hline Rutul & dene & $\begin{array}{l}\text { 'piece, unit', 'seed, } \\
\text { kernel' }\end{array}$ & $\begin{array}{l}\text { Dzhamalov and Semedov (2006: } \\
97 \text { ) }\end{array}$ \\
\hline Khinalug & dänä & 'a few, a little’ & Ganieva (2002: 97) \\
\hline Lezgian & - & & $\begin{array}{l}\text { Gadzhiev (1950), Gadzhiev and } \\
\text { Talibov (1966) }\end{array}$ \\
\hline Tabasaran & - & & $\begin{array}{l}\text { Khanmagomedov and Shalbuzov } \\
(2001)\end{array}$ \\
\hline Agul & - & & $\begin{array}{l}\text { Sulejmanov (2003), Ramazanov } \\
(2010)\end{array}$ \\
\hline Archi & - & & Chumakina et al. (2007) \\
\hline
\end{tabular}

by Ismailova (2011), based on the central dialect of Mukhad, does not mention any dänä-like words, the dictionary of the peripheral Ikhrek dialect by Dzhamalov and Semedov (2006: 97) has an entry dene '1. piece, unit (цтука); 2. seed, kernel (семя, ядро)'. The only example (40) they provide is unclear, as the translation reads simply 'one piece', although it seems that the correct meaning should be rather 'one matchstick'. Interestingly, the Tsakhur-Russian dictionary by Ibragimov and Nurmamedov (2010: 150) only gives the meaning 'piece, unit (штука)' for dene, with the example in (41). In (40) and (41), dene is the NP head whose dependent ('matchstick' and 'chestnut', respectively) takes the form of the attributive, which covers genitive functions in both languages, cf. Tsakhur sa Xaral c'abl-ar-ši-na [one sack chestnut-PL-OBL-ATTR] 'a sack of chestnuts'. 
išbišk'-i-jd dene matchstick-OBL-ATTR piece 'one piece' / 'one matchstick?' (Dzhamalov and Semedov, 2006: 97)

sa dene c'abil-a-na
one piece chestnut-OBL-ATTR
'one chestnut' (Ibragimov and Nurmamedov, 2010: 15O)

The dictionary appended to the Mishlesh Tsakhur grammar mentions two words, den for 'grain' and dene referring to something small, cf. 'fraction, kernel, corn (частииа массы; зернышико; крупинка; спичинка)'. Unfortunately, no examples are provided in Kibrik and Testelec (1999), but the sections on numerals and on the noun phrase in the grammar do not mention any uses of dene as a function word.

The data summarized in Table 5 shows that there is a south-to-north cline among the Lezgic languages with respect to the existence of a borrowed dänä-like word. All languages spoken in Azerbaijan (Tsakhur, Rutul, Budugh, Kryz, Udi) do have it, at least in some dialects. Tsakhur and Udi even have two words, corresponding to the difference between Azerbaijani dan 'grain' vs. dənə 'grain'/'counting word'. Agul, Tabasaran, Lezgian and Archi have not borrowed any of these words. Generally speaking, with the exception of Lezgian proper, the existence of dänä-like words corresponds to the distance from Azerbaijani-speaking area.

The Khinalug case is a special one. According to Ganieva's dictionary, dänä is only used as an adverb 'a few, a little (немного, мало)', cf. her examples lap

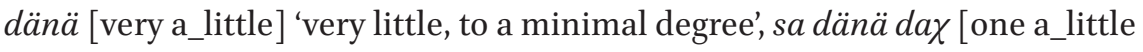
early] 'not long ago, a bit earlier', or a complex verb dänä kiri [a_little do] 'to diminish, make smaller, reduce' (Ganieva, 2002: 97). However, Monika Rind-Pawlowski informed me (p.c., 13.01.2019), that dänä is also attested as a numeral classifier with countable nouns, cf. (42) with a numeral 'seven' preceded by sa 'one' which is already familiar to us from Udi as an "approximizer" in numeral phrases. ${ }^{15}$

sa yeddi dänä karpa attıq'-thar-mä
[one seven CLSF lamb] take_up-ITER-PRS
'We take about seven lambs up over there.'

15 Both Khinalug examples (42) and (43) were provided to me by Monika Rind-Pawlowski and were extracted from her Khinalug corpus. 
For dänä, the adverbial meaning 'a little' is clearly dominating, and the use as a classifier is rather an exception. However, besides dänä, Khinalug has a numeral classifier which does not appear to be a loan, namely $\chi e l$, see (43). ${ }^{16}$ According to Monika Rind-Pawlowski, this classifier is only used when the number refers to a smaller amount versus a larger amount (e.g., ten cows from the herd, two houses among all the houses in the village, one son who is left after the other children died, etc.). To the contrary, dänä is neutral in this respect and is not limited to contexts where a small amount out of a large amount is referred to.
a. k'u хel misic'oa

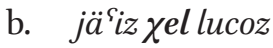
c. sa ұel šime

[two CLSF small house]

[ten CLSF cow]

[one CLSF son-is]

'two small houses'

'ten cows'

'it is one son'

We see from this preliminary report from a language expert that it is not only Udi which has a numeral classifier previously undescribed as such in the literature. We also see that it is not only a Turkic/Iranian borrowed item (in particular, dänä) that can be used in the classifier function. More work should be done here to get a finer picture. For the time being, however, Udi remains the only known Lezgic language to employ a numeral classifier borrowed from Azerbaijani (ultimately, from Iranian), and Khinalug is possibly another Nakh-Daghestanian language with a small classifier system, partly influenced by Azerbaijani as well.

As regards the word tan, we do not find it in other Lezgic languages or in (modern) Azerbaijani with the meaning 'person' or as a counting word. Azerbaijani dictionaries only mention the obsolete word tan 'body', stating its Persian origin (Tağıyev, 2006, vol. 4: 496; Orucov, 2006, vol. 4: 310), cf. an example from the former dictionary Na qadar tanda var canım 'as long as there is soul in the body' ${ }^{\prime 7}$ This word has also found its way into some Lezgic languages with the meaning 'body' or 'trunk (of a tree), stem (of a plant)'. Thus, both meanings are given for the word tan in dictionaries of the three East Lezgic languages (Lezgian, Tabasaran and Agul), cf. Lezgian gürčeg tan awaj ruš 'a girl with a beautiful figure', lit. "beautiful body having girl". Kibrik and Kodzasov (199o: 19) mention Kryz tän as one of the two words for 'body' alongside žěndäk, and Klimov and Khalilov (2003: 100) give Tsakhur tan as one of the two words for 'body' alongside žan. Other Lezgic languages and Khinalug seem to lack this word.

16 Ganieva (2002: 308) only mentions the meanings 'one of a pair' and 'name for two identical

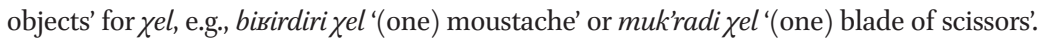

17 There is also another (homonymous?) word tan used as an adjective 'equal, bilateral' and an adverb 'equally, on a par' (Tağıyev, 2006, vol. 4: 496; Orucov, 2006, vol. 4: 310). 
Given that the form of the word in most languages is tan and not tän, it may be that the word was borrowed directly from Persian and not via Azerbaijani. Note that in all these languages tan (or tän) seems to be peripheral as a word for 'body', or possibly has an archaic or poetic nuance. The basic words for 'body' in the Lezgic languages are different, e.g., క̌an or beden (which, in their turn, are also borrowings).

\section{Conclusion: the Peripheral Nature of the Udi System of Numeral} Classifiers

Classifiers are commonly defined as morphemes which denote "some salient perceived or imputed characteristics of the entity to which an associated noun refers" (Allan, 1977: 285), the choice of a classifier being "predominantly semantic" (Aikhenvald, 2000: 125). Accordingly, Gil (2013) states that "one of the most salient functions" of sortal numeral classifiers, which are one of the major classifier types in the languages of the world, is "to divide the inventory of count nouns into semantic classes, each of which is associated with a different classifier". The choice of a numeral classifier "is dictated by the semantic characteristics of the referent of the head of a noun phrase", which may be animacy, humanness, sex, social status or age, physical or functional properties, arrangement and quanta (Aikhenvald, 2000: 13, 17, 117, 286-293).

The reduced, even with respect to the "small-inventory classifier systems", classifier system of Udi with its single universal numeral classifier dänä, cannot be attributed the function of noun categorization. The Udi classifier co-occurs with both human and inanimate noun phrases and is not obligatory. It looks rather as an additional optional element of a numeral phrase, lacking any particular semantic content. At the same time, Aikhenvald (2000: 333) stresses that "[a]ll non-obligatory classifier systems have some discourse-pragmatic functions": the use of classifiers "correlates with referentiality, specificity, definiteness, topical continuity, and the salience in discourse of the noun". In particular, in some languages (e.g., Japanese, Malay, Burmese) numeral classifiers often occur with nouns in NPs used for initial mentions of referents (Aikhenvald, 2000: 324).

It is far from clear at the present stage of research whether the use of dänä in Udi has a clear-cut discourse/pragmatic function. Judging from textual examples, the classifier construction with dänä can indeed occur for introductory reference. Thus, (44) shows the use of dänä with a human referent ('three friends') in the first sentence of a narrative, while the next reference to the same group is made without dänä. On the other hand, however, the 
introductory context does not obligatorily entail the use of the classifier, as illustrated by example (45) (from a different story).

\begin{tabular}{|c|c|c|c|}
\hline $\begin{array}{l}b a=n e=k-s a \\
b e=3 S G=S T-P R S\end{array}$ & $\begin{array}{l}\text { xib } \\
\text { three }\end{array}$ & $\begin{array}{l}\text { dänä } \\
\text { CLSF }\end{array}$ & $\begin{array}{l}\text { joldaš. (...) } \\
\text { friend] }\end{array}$ \\
\hline xib & joldaš-axun & & pro ${ }^{\varsigma}{ }^{-}-0$ \\
\hline
\end{tabular}

'There live three friends. \{They work at the rice mill where they grind rice.\} Two of these three friends are good.' (NSC, 2004)

$$
\begin{array}{lllll}
b a=n e=k-s a, & t e=n e & b a k-s a & p: a^{\varsigma} & \text { viči. } \\
\text { be=3SG=ST-PRS } & \text { NEG=3SG } & \text { be-PRS } & \text { [two } & \text { brother] }
\end{array}
$$

'There live (lit. there are, there are not) two brothers.' (NSC, 2006)

According to Stilo (2018: 141), in most of the relevant languages of the AraxIranian area classifiers are "optional even in colloquial registers" (there are exceptions like Mazanderani, Gilaki and Muslim Caucasian Tat, where the use of classifiers is fully obligatory in the available corpora). The conditions under which the optional classifiers do appear are not addressed by Stilo or most other works, ${ }^{18}$ so it is yet to be investigated whether Udi has borrowed the classifier together with a corresponding function, or it has developed its current distribution independently from the source language. The corpus data available so far are still too scarce for a definitive conclusion.

Being undoubtedly contact-induced, the Udi classifier system occupies a peripheral position among the languages of the area for which the phenomenon of "small-inventory classifier systems" is distinctive. As Stilo (2014: 279) argues, the classifier isogloss "is fairly widespread in the eastern AILA areas but fades out in the north and the west (except for Turkish)". Thus, while Azerbaijani and Turkish, which have borrowed the classifiers from Iranian languages, "have completely integrated them into their noun phrase domains", Aramaic dialects of the area have been affected by Iranian classifier systems "much more marginally than Turkic" (Stilo, 2018: 136). The "fade-out" of the numeral classifiers in the area can be observed in three ways: frequency, class

18 A rare exception is Schroeder (1999: 96-97, 103-104, 108), who argues that in Turkish the classifier tane is "a marker of high pragmatic referentiality" which is preferably used when either a small number of [+new] referents is introduced in the discourse, or topicalized subsequent to their introduction, or a referent "is introduced as an antecedent set for subsequent (partitive) reference to a subset from this set". The use of tane is thus "primarily motivated by pragmatic consderations" and is related to the function of marking certain referents as "distinct". 
membership, and/or domain. ${ }^{19}$ As an example, Stilo (2018: 159-161) mentions Lorri Armenian and Jewish Sanandaj Aramaic in which the majority of nouns with numerals occur without classifiers, and corpora for these three languages show no human numeral classifier for human nouns, only the universal numeral classifier. Along another geographical cline, Georgian occupies the extreme position with a single classifier-like element $c^{h}$ ali which, however, is highly reduced in colloquial language in all three parameters indicative for fade-out phenomena (frequency, class membership and domain).

If we apply the same criteria to Udi, we can easily see that it is very close to the languages demonstrating the "fade-out" effects of classifier systems, like Georgian or Jewish Aramaic. Udi did not copy the human numeral classifier neefer/nəfar from Iranian (or Azerbaijani) and is thus a language with just one classifier proper dänä (or "one and a half", if we count semi-classifier tan). The frequency of dänä is quite low, so that the majority of nouns occur with numerals without classifiers. At the same time, dänä is compatible with both inanimates and humans, so it does not literally "classify" nouns in any semantic groups.

To conclude, the position of Udi as a language with a small, even extremely small, classifier system, is intermediate between the other Nakh-Daghestanian languages, on one hand, and languages of the Araxes-Iran Linguistic Area, on the other. Among the Nakh-Daghestanian languages, Udi may be unique in having at least one classifier (Khinalug may be another exception, as outlined above), as the languages of the family typically lack them altogether. Among the AILA languages with their predominantly two-classifier systems, Udi belongs to the peripheral zone and, like some other peripheral languages, can be said to be "transitional to areas where there are no vestiges of classifiers" (Stilo, 2018: 136).

\section{Acknowledgements}

The article was prepared within the framework of the HSE University Basic Research Program. I wish to thank my long-term collaborators on the (still ongoing) UDILANG project, Dmitry Ganenkov and Yury Lander. My thanks are also due to Vladislav Dabakov for consultations on Udi, and to Don Stilo and Samira Verhees for discussion of the data and for kindly improving the English

19 See also Stilo (2012) where the existence of prepositions vs. postpositions in the languages of the Araxes-Iran Linguistic Area is analysed as an example of a "fade-in/fade-out" phenomenon. 
of this paper. This work is dedicated to the memory of Wolfgang Schulze (1953-2020).

\section{Abbreviations}

\begin{tabular}{|c|c|}
\hline 2,3 & person \\
\hline 3s:POss & third singular, possessive \\
\hline $\mathrm{ABL}$ & ablative \\
\hline ACC & accusative \\
\hline $\mathrm{AD}$ & adessive \\
\hline $\mathrm{ADD}$ & additive \\
\hline $\mathrm{ADV}$ & adverb \\
\hline AOC & aorist converb \\
\hline AOR & aorist \\
\hline ATTR & attributive \\
\hline $\mathrm{BE}$ & (defective) existential verb \\
\hline BEN & benefactive \\
\hline CAUS & causative \\
\hline CLSF & classifier \\
\hline $\mathrm{COP}$ & copula \\
\hline DAT & dative \\
\hline DEB & debitive \\
\hline DIST & distal \\
\hline ERG & ergative \\
\hline GEN & genitive \\
\hline $\mathrm{HNC}$ & human numeral classifier \\
\hline IMP & imperative \\
\hline INF & infinitive \\
\hline ITER & iterative \\
\hline LOC & locative \\
\hline LV & light verb (in complex verbs) \\
\hline MSD & masdar \\
\hline NEG & negation \\
\hline NMLZ & nominalization \\
\hline овL & oblique stem \\
\hline PERSON & classifier-like word 'person' \\
\hline PL & plural \\
\hline РОт & potential future \\
\hline PRF & perfect \\
\hline
\end{tabular}




$\begin{array}{ll}\text { PROX } & \text { proximal } \\ \text { PRS } & \text { present } \\ \text { PST } & \text { past } \\ \text { PT:IPF } & \text { imperfective participle } \\ \text { PT:PF } & \text { perfective (aorist) participle } \\ \text { PTCL } & \text { particle } \\ \text { RDP } & \text { reduplication } \\ \text { SG } & \text { singular } \\ \text { ST } & \text { detached part of verb stem } \\ \text { UNC } & \text { universal numeral classifier }\end{array}$

\section{References}

Aikhenvald, Alexandra Y. 20oo. Classifiers: A typology of noun categorization devices. Oxford: Oxford University Press.

Alekseev, Mikhail E. 1985. Voprosy sravnitel'no-istoričeskoj grammatiki lezginskix jazykov.Morfologija. Sintaksis [Problems of the comparative-historical reconstruction of the grammar of Lezgic languages: Morphology. Syntax]. Moscow: Nauka.

Allan, Keith. 1977. Classifiers. Language 53: 284-310.

Authier, Gilles. 2009. Grammaire Kryz (Langue caucasique d'Azerbaïdjan, dialecte d'Alik). Leuven-Paris: Peeters.

Bežanov, Mikhail. 1888. Rustam (udinskaja skazka) [Rustam (Udi fairy-tale)]. Sbornik materialov dlja opisanija mestnostej i plemën Kavkaza. vi, priloženie, 7-28.

Bežanov, Semën. 19o2. Gospoda Našego Iisusa Xrista Svjatoe evangelie ot Matfeja, Marka, Luki i Ioanna na russkom i udinskom jazykax [The Holy Gospel according to Matthew, Mark, Luke and John in Russian and Udi]. Sbornik materialov dlja opisanija mestnostej i plemën Kavkaza. Xxx.

Çejrani, Ţөder and Mixak Çeirani. 1934. Samçi dəs [First lesson]. Suxum: Abgizen Ţərbi. Chumakina, Marina, Dunstan Brown, Greville Corbett, and Harley Quilliam. 2007. A dictionary of Archi: Archi-Russian-English (Online edition). University of Surrey. Available online at http://dx.doi.org/10.15126/SMG.16/2.

Comrie, Bernard and Madzhid Khalilov. 2010. The dictionary of languages and dialects of the peoples of the Northern Caucasus. Leipzig: MPI Evolutionary Anthropology.

CPUT - Corpus of Published Udi Texts, entered and slightly corrected by Wolfgang Schulze, Gräfensteinberg, 2003-2005; TITUs version (with corrections and additions) by Jost Gippert, Frankfurt a/M, 27.12.2010. Available online at http://titus. fkidg1.uni-frankfurt.de/texte/etcs/cauc/udi/cput/cput.htm.

Daniel, Michael and Dmitry Ganenkov. 2009. Case marking in Daghestanian: limits of elaboration. In Andrej Malchukov and Andrew Spencer (eds.), The Oxford handbook of case, 668-685. Oxford: Oxford University Press. 
Dirr, A[dolf]. M. 1903. Grammatika udinskogo jazyka [Udi grammar]. Sbornik materialov dlja opisanija mestnostej i plemën Kavkaza. XXXIII, otdel 4, 1-101.

Dirr, Adolf. 1928. Udische Texte. Caucasica 5: 6o-72.

Dryer, Matthew S. 2013. Indefinite Articles. In Matthew S. Dryer and Martin Haspelmath (eds.), The World Atlas of Language Structures Online. Leipzig: Max Planck Institute for Evolutionary Anthropology. Available online at http://wals.info/chapter/38.

Dzhamalov [Džamalov], Kamal È. and Semed A. Semedov. 20o6. Rutul'sko-russkij slovar' (ixrekskij dialekt) [Rutul-Russian dictionary (Ikhrek dialect)]. Moscow: È KON-Inform.

Fähnrich, Heinz. 1999. Kleines Udisch-Deutsches Wörterverzeichnis. Jena: Friedrich-Schiller-Universität.

Gadzhiev [Gadžiev], Magomed M. 1950. Russko-lezginskij slovar' [Russian-Lezgian dictionary]. Makhachkala: Izd-vo Dagestanskogo filiala Akademii nauk sss R.

Gadzhiev [Gadžiev], Magomed M. and Bukar B. Talibov. 1966. Lezginsko-russkij slovar' [Lezgian-Russian dictionary]. Moscow: Sovetskaja Ènciklopedija.

Ganenkov, Dmitry, Yury Lander and Timur Maisak. 2010. From interrogatives to placeholders in Udi and Agul spontaneous narratives. In Nino Amiridze, Boyd Davis and Margaret Maclagan (eds.), Fillers, Pauses, and Placeholders, 95-118. (Typological Studies in Language, 93). Amsterdam: Benjamins.

Ganenkov, Dmitry and Timur Maisak. 2020. Nakh-Daghestanian languages: a family survey. In Maria Polinsky (ed.), The Oxford handbook of languages of the Caucasus, 87-145. Oxford: Oxford University Press.

Ganieva, Faida A. 2002. Khinalugsko-russkij slovar' [Khinalug-Russian dictionary]. Makhachkala: DNC RAN.

Gil, David. 2013. Numeral Classifiers. In Matthew S. Dryer and Martin Haspelmath (eds.), The World Atlas of Language Structures Online. Leipzig: Max Planck Institute for Evolutionary Anthropology. Available online at http://wals.info/chapter/55.

Gippert, Jost, Wolfgang Schulze, Zaza Aleksidze, and Jean-Pierre Mahé. 20o8. The Caucasian Albanian palimpsests of Mount Sinai. Edition and interpretation. 2 vols. Turnhout: Brepols.

Gukasjan, Voroshil L. 1973. Vzaimootnošenija azerbajdžanskogo i udinskogo jazykov [Relations between the Azerbaijani and Udi languages]. Doctoral dissertation abstract. Baku: Elm.

Gukasjan, Voroshil L. 1974. Udinsko-azerbajdžansko-russkij slovar' [Udi-AzerbaijaniRussian dictionary]. Baku: Èlm.

Ibragimov, Garun Kh. and Yunus M. Nurmamedov. 2010. Caxursko-russkij slovar' [Tsakhur-Russian Dictionary]. Makhachkala: D GPU.

Ismailova, Èminat I. 2011. Russko-rutul'skij slovar' [Rutul-Russian Dictionary]. Makhachkala: IJaLI DNC RAN.

Kassian, Alexei. 2015. Towards a formal genealogical classification of the Lezgian languages (North Caucasus): testing various phylogenetic methods on lexical 
data. PLoS ONE 10(2): 1-25. Available online at http://journals.plos.org/plosone/ article?id=10.1371/journal.pone.0116950.

Khanmagomedov, Bejdullakh G.-K. and Kim T. Shalbuzov. 2001. Tabasaransko-russkij slovar' [Tabasaran-Russian Dictionary]. Moscow: Nauka.

Kibrik, Aleksandr E. 2003. Nominal inflection galore: Daghestanian, with side glances at Europe and the world. In Frans Plank (ed.), Noun phrase structure in the languages of Europe, 37-112. Berlin: De Gruyter.

Kibrik, Aleksandr E. and Sandro V. Kodzasov. 1990. Sopostavitel'noe izučenie dagestanskix jazykov. Imja. Fonetika [Comparative study of Daghestanian languages. Noun. Phonetics]. Moscow: MGU.

Kibrik, Aleksandr E. and Jakov G. Testelec (eds.). 1999. Èlementy caxurskogo jazyka $v$ tipologičeskom osveščenii [Aspects of the Tsakhur language from a typological perspective]. Moscow: Nasledie.

Kıral, Filiz.2001.Das gesprochene AserbaidschanischvonIran. Wiesbaden:Harrassowitz. Klimov, Georgij A. and Madzhid Sh. Khalilov. 20o3. Slovar' kavkazskix jazykov. Sopostavlenie osnovnoj leksiki [Dictionary of Caucasian languages: comparison of the basic lexicon]. Moscow: Vostočnaja literatura RAN.

Lander, Yury. 2013. Contact-induced features in the Udi noun phrase. Paper presented at the 46th Annual Meeting of the Societas Linguistica Europaea, Split, 19 September 2013.

Lazard, Gilbert. 1992. Grammar of Contemporary Persian. Costa Mesa, CA: Mazda.

Mahootian, Shahrzad and Lewis Gebhardt. 1997. Persian. (Descriptive Grammars.) London: Routledge.

Maisak, Timur. 2019. Borrowing from an unrelated language in support of intragenetic tendencies: the case of the conditional clitic $=s a$ in Udi. Diachronica $36(3): 337-383$.

Mejlanova, Unejzat A. 1984. Buduxsko-russkij slovar' [Budugh-Russian Dictionary]. Moscow: Nauka.

Mobili, Robert. 2010. Udi-azerbaycanin-urusin əyitluğ. Bakı: Qrifli nəşr.

Noorlander, Paul M. and Donald Stilo. 2015. On the convergence of verbal systems of Aramaic and its neighbours. Part I: Present-based paradigms. In Geoffrey Khan and Lidia Napiorkowska (ed.), Neo-Aramaic and its linguistic context, 426-452. Piscataway, NJ: Gorgias Press.

Orucov, Әliheydər (red.). 20o6. Azərbaycan dilinin izahlı lüğəti. 4 vols. Bakı: Şərq-Qərb.

Pančvize [Panchvidze], Vladimir N. 1974. Udiuri enis gramat'ik'uli analizi [Grammatical analysis of the Udi language]. Tbilisi: Mecniereba.

Perepis'. 1989. Vsesojuznaja perepis' naselenija 1989g. Raspredelenie naselenija Azepbajdžanskoj SSR po naibolee mnogočislennym nacional'nostjam i jazyku [The 1989 Soviet census: Distribution of the Azerbaijan SsR population by the largest ethnicities and language]. Available online at http://www.demoscope.ru/weekly/ ssp/sng_nac_lan_89_az.php. 
Ramazanov, Muslim R. 2010. Agul'sko-russkij slovar' [Agul-Russian dictionary]. Makhachkala: Lotos.

Schiefner, Anton A. 1863. Versuch über die Sprache der Uden. Mémoires de l'Académie impériale des sciences de St.-Pétersbourg, 7 série, tome VI, no. 8: 1-110.

Schroeder, Christoph. 1999. The Turkish nominal phrase in spoken discourse. Wiesbaden: Harrassowitz.

Schulze, Wolfgang. 1982. Die Sprache der Uden in Nordazerbajdžan. Studien zur Synchronie und Diachronie einer süd-ostkaukasischen Sprache. Wiesbaden: Harrassowitz.

Schulze, Wolfgang. 2001. The Udi Gospels: Annotated text, etymological index, lemmatized concordance. München: Lincom Europa.

Schulze, Wolfgang. 2001/2. The Udi language: A grammatical description with sample text. Available online at http://wschulze.userweb.mwn.de/Udigenı.htm.

Schulze, Wolfgang. 2002. The loan layers of Udi: Armenian. In Wolfram Bublitz, Manfred von Roncador and Heinz Vater (eds.), Philology, Typology and Language Structure. Festschrift for Winfried Boeder on the Occasion of his 65th Birthday, 211223. Frankfurt/Main: Lang.

Schulze, Wolfgang. 2005. Towards a history of Udi. International Journal of Diachronic Linguistics 1: 55-91.

Schulze, Wolfgang. 2015a. From Caucasian Albanian to Udi. Iran and the Caucasus 19: 149-177.

Schulze, Wolfgang. 2015b. Aspects of Udi-Iranian language contact. In Uwe Bläsing, Victoria Arakelova and Matthias Weinreich (eds.), Studies on Iran and the Caucasus. In honour of Garnik Asatrian, 373-401. Leiden: Brill.

Schulze, Wolfgang. 2016a. How much Udi is Udi? In Ramazan Korkmaz and Gürkan Doğan (eds.), Endangered languages of the Caucasus and beyond, 187-208. Leiden: Brill.

Schulze, Wolfgang. 2016b. Udi. In Peter O. Müller, Ingeborg Ohnheiser, Susan Olsen, and Franz Rainer (eds.), Word-Formation: An international handbook of the languages of Europe, 3564-3578. (HSK Handbücher zur Sprach- und Kommunikationswissenschaft 40/5.) Berlin: De Gruyter.

Schulze, Wolfgang. 2016c. Textual Resources for Udi. In Natia Reineck and Ute Rieger (eds.), Kaukasiologie heute - Festschrift für Heinz Fähnrich zum 7o. Geburtstag, 361381. Jena: Buchverlag König.

Schulze-Fürhoff, Wolfgang. 1994. Udi. In Rieks Smeets (ed.), The Indigenous Languages of the Caucasus, vol. 3. North East Caucasian languages, part 2, 447-514. Delmar, N.Y.: Caravan.

Širaliev, Mamedaga Š. and Èrvand V. Sevortjan (eds.). 1971. Grammatika azerbajdžanskogo jazyka [A grammar of Azerbaijani]. Baku: Elm. 
Statistical Committee. 2009. Distribution of population by native language and freely command of languages (based on 2009 population census). The State Statistical Committee of the Republic of Azerbaijan: Population by ethnic groups, by native language and freely command of languages. Available online at https://www.stat. gov.az/source/demoqraphy/en/oo1_11-12en.xls.

Stilo, Donald L. 2012. Intersection zones, overlapping isoglosses, and 'fade-out/fade-in' phenomena in Central Iran. In Behrad Aghaei and M. R. Ghanoonparvar (eds.), Iranian Languages and Culture: Essays in honor of Gernot Ludwig Windfuhr, 134-155. Costa Mesa, CA: Mazda Publishers.

Stilo, Donald L. 2014. Further notes on the Iranian substratum of Azerbaijani Turkish. In Heidi Stein (ed.), Turkic Language in Iran - Past and Present, 271-293. Wiesbaden: Harrassowitz Verlag.

Stilo, Donald L. 2015. An introduction to the Atlas of the Araxes-Iran Linguistic Area. In Bernard Comrie and Lucía Golluscio (eds.), Language contact and documentation. Contacto lingüístico y documentación, 343-355. Berlin: Walter De Gruyter.

Stilo, Donald L. [Don]. 2018. Numeral classifier systems in the Araxes-Iran linguistic area. In William B. McGregor and Søren Wichmann (eds.), The diachrony of classification systems, 135-164. Amsterdam: John Benjamins.

Sulejmanov, Nadir D. 2003. Agul'sko-russkij (dialektologičeskij) slovar' [Dialectological Agul-Russian dictionary]. Makhachkala: IJaLI DNC RAN.

Tağıyev, Məmməd Tağı oğlu (red.). 20o6. Azərbaycanca-rusca lüğət. 4 vols. Bakı: Şərq-Qərb.

Talibov, Bukar B. 2007. Buduxskij jazyk [The Budukh language]. Moscow: Academia. van den Berg, Helma. 2005. The East Caucasian language family. Lingua 115: 147-19o. Windfuhr, Gernot and John R. Perry. 2oog. Persian and Tajik. In Gernot Windfuhr (ed.), The Iranian languages, 416-544. London, New York: Routledge.

Žeiranišvili [Dzheiranishvili], Evgenij F. 1971. Udiuri ena. Gramat'ik'a, krestomat'ia, leksik'oni [Udi: grammar, texts, lexicon]. Tbilisi: Tbilisi university gamomcemloba.

\section{Published sources in Nizh Udi}

Aydınov, Y. A. and J. A. Keçaari. Olifba (Tletıir). Bəkü, 1996a.

Aydınov Y. A., Keçaari J. A. Udin muz (udi dili) 3. Bakı, 1996b.

Dabakov, V. Nanaj muz (Rodnojjazyk). Šaxty, 2013.

Dabakov, V. V. Udiğoy folklor: Nağılxo. Legendoox. Astrakhan, 2007.

Miller and Antonova 2012 = Ľvel girkaxun 25 çureğala exlatxo / Nağll balo: Yura Miller, Udi muza taradiyo: Venera Antonova. [TGS International,] 2012. 
Keçaari [Kečaari], Ž. Nana očal: Šeirxo, hekjatxo, drama. Baku, 1996.

Keçaari, K. Orayin. Bakı, 2001.

Keçaari, K. Buruxmux. Gəncə, 2003.

Luke 2011 = Luk'an exlotbi Mŭq Xavar. Bakı, 2011.

Ruth-Iona 2009 = Rut', İona. Chambersburg, 2009 . 